\title{
CALCINED BONE AS A RELIABLE MEDIUM FOR RADIOCARBON DATING: A TEST USING PAIRED NORTH AMERICAN SAMPLES
}

\author{
James C. Chatters, James W. Brown, Steven Hackenberger, Patrick McCutcheon, \\ and Jonathan Adler
}

\begin{abstract}
Radiocarbon dating using charcoal and bone collagen, two standards of archaeological chronology, can be difficult to impossible in environments where natural burning is common and bone does not preserve well. In such settings, charcoal ages cannot always be trusted and collagen is unavailable. Calcined bone can be a viable alternative medium in these situations but it has rarely been exploited in the Americas. One area that could benefit from its use is the forested Pacific Northwest. We compare calcined bone ages with charcoal and/or collagen dates from individual features or discrete cultural strata in 10 Washington, Oregon, Idaho, and British Columbia sites dating between 9000 and 100 B.P. Resulting radiocarbon age estimates based on calcined bone closely match those based on charcoal and/or collagen in nearly all cases. We obtained calcined bone dates from three additional Holocene-aged sites that had not previously produced accurate results, obtaining findings consistent with estimates based on cross dating. Preserving well where all other organic media of cultural origin are lost or unreliable, calcined bone holds promise for dating sites in conifer forests and other acidic soil settings, and can allow researchers to refine archaeological sequences that have long defied accurate chronometric analysis.
\end{abstract}

La datación por radiocarbono usando carbón y colágeno óseo, dos estándares para la cronología arqueológica, puede ser difícil o imposible en ambientes donde los incendios naturales son comunes y el material óseo no se conserva bien. En tales condiciones los resultados del fechamiento por carbón no siempre son confiables y el colágeno no puede ser recuperado. La datación de hueso calcinado puede ser una técnica alternativa viable en estas situaciones, pero rara vez se ha explotado en América. Un área que podría beneficiarse de su uso es el boscoso Noroeste del Pacífico de Norteamérica. Se compararon las edades de fragmentos de hueso calcinado con aquellas de muestras de carbón o colágeno desde fogatas, estructuras individuales o estratos culturales discretos en 10 sitios de Washington, Oregón, Idaho y Columbia Británica que datan entre 9000 y 100 a.P. Las estimaciones resultantes de la edad de radiocarbono sobre hueso calcinado coinciden con aquellas procedentes de carbón o colágeno en casi todos los casos. Se obtuvieron fechas sobre hueso calcinado para tres sitios adicionales que previamente no habían producido resultados precisos, obteniendo fechas coherentes con las estimaciones basadas solamente en estilo cultural. Dado que se conserva bien en contextos donde se pierden o no son confiables todos los demás medios orgánicos de origen cultural, el hueso calcinado representa una promesa para la datación de sitios en bosques de coníferas y otros ambientes con suelos ácidos, permitiendo refinar las secuencias arqueológicas que previamente habían desafiado un análisis cronométrico preciso.

A ge estimation is critical to archaeological research, and radiocarbon dating is the method of choice for the Holocene and terminal Pleistocene. However, reliable radiocarbon dates can be difficult to obtain in some environmental or geological con- texts. Among the most challenging are forested landscapes, particularly those with slow sedimentation rates. Forests have high fuel loads subject to intense natural burning and experience high levels of bioturbation, making age estimates based on charcoal or wood questionable

James C. Chatters and Jonathan Adler $\square$ DirectAMS, Suite 107, 11822 North Creek Parkway North, Bothell, WA 98011, USA (paleosci@gmail.com, corresponding author Chatters)

James W. Brown $\square$ Department of Anthropology, Washington State University, Pullman, WA 99163, USA

Steven Hackenberger and Patrick McCutcheon $\square$ Department of Anthropology, Central Washington University, Ellensburg, WA 98926, USA

American Antiquity 82(3), 2017, pp. 593-608

Copyright (C) 2017 by the Society for American Archaeology

doi:10.1017/aaq.2017.27 
outside discrete, unequivocal feature contexts. Forest soils tend to be moist and acidic, resulting in rapid degradation of both the organic and mineral phases of bone. Thus, both of the most relied upon media for radiocarbon dating can be unavailable or, worse, misleading and impede the development of accurate cultural chronologies.

European archaeologists, who also face this problem, have begun to use a previously overlooked medium for radiocarbon dating: calcined bone. Calcined bone is resistant to acid dissolution (van Strydonck et al. 2005) and thus often survives in archaeological contexts even when all other bone and tooth materials have perished. It is produced only under extremely high heat, making it more confidently attributable than charcoal to human activity. Focusing on human cremations, multiple European researchers have compared radiocarbon ages of calcined bone with ages of directly associated charcoal, bone collagen, and other organics and consistently found close age congruity for samples dating as far back as 20,000 years (Lanting et al. 2001; Olsen et al. 2008; Zazzo et al. 2013). Despite the successes experienced by our Old World colleagues, American archaeologists have been slow to adopt calcined bone as a dating medium (but see Surovell et al. 2016).

One region that could benefit from exploiting this medium is the northwest coast of North America, a heavily forested environment where acid soil and ubiquitous charcoal make radiocarbon dating difficult outside of shell middens; consequently, many parts of the region lack precisely dated archaeological chronologies. To explore the potential of calcined bone for alleviating this problem, we compared charcoal and collagen dates with dates obtained from calcined bone from 10 previously investigated archaeological sites in Washington, Oregon, Idaho, and British Columbia. Obtaining results comparable to those of European researchers, we then used this medium to determine the ages of four archaeological components that had heretofore defied radiometric dating.

\section{The Process of Bone Calcination}

Bone consists of an organic framework of collagen onto which small, weak crystals of inorganic bioapatite precipitate. Bioapatite is a hydroxyapatite form of calcium phosphate in which up to 6 percent of the phosphate ions are replaced by carbonate in the crystal matrix (Huls et al. 2010). This inorganic carbon fraction is referred to as structural carbonate; collagen is the principal form of organic carbon in bone. Radiocarbon dates on bone are based on $\mathrm{CO}_{2}$ produced by either combustion of the acid-extracted collagen fraction or acid digestion of the structural carbonate fraction. Because the bioapatite crystals in bone are small, weak, and loosely packed, the structural carbonate fraction is subject to contamination by carbonates in diagenetic waters (van Strydonck et al. 2005; Zazzo et al. 2009). As a result, radiocarbon ages of bone bioapatite tend to be strongly affected by dissolved inorganic carbon in all but the most arid environments (Cherkinsky 2009; Zazzo and Saliege 2011).

When bone is burned, it goes through a series of stages that begin with discoloration and denaturing of the collagen, followed by charring, total combustion of the organic fraction, combustion of the inorganic carbon fraction, and finally recrystallization of the bioapatite (McCutcheon 1992; Shipman et al. 1984). Temperature of combustion is the controlling factor in this process. All organic carbon has burned away by around $600^{\circ} \mathrm{C}$, at which point bone color has shifted from gray to light bluish-gray. By $650^{\circ} \mathrm{C}$ the bone has become pure white. This is the calcined state.

$\mathrm{X}$-ray diffraction (XRF) and Fourier transform infrared spectroscopy (FTIR) of bone at progressive stages of burning have shown that the hydroxyapatite crystals remain small, weakly structured, and loosely organized below $650^{\circ} \mathrm{C}$, at which point they recrystallize into larger, more regular, closely packed hexagonal forms (McCutcheon 1992; Shipman et al. 1984; Stiner et al. 1995; Zazzo et al. 2009). Holden and colleagues (1995) found that crystal sizes increase from $0.06 \pm 0.07 \mu \mathrm{m}$ at lower temperatures to between $0.41 \pm$ 0.09 and $0.25 \pm 0.07 \mu \mathrm{m}$ in fully calcined bone. Compaction and crystal structure create a physical barrier that protects carbonate remaining in the bone from contamination by carbonates dissolved in surrounding waters; it has effectively become a closed system, at least for the Holocene (van Strydonck et al. 2005; Zazzo et al. 2012). In 
this recrystallized condition, the hydroxyapatite in bone is more structurally similar to that of tooth enamel (Van Strydonck et al. 2009).

Unburned bioapatite consists of approximately 1 percent carbon by weight; calcined bone contains a tenth that amount (Lanting et al. 2001). Initially, this residual carbonate was thought to have derived from the structural carbonate fraction of the original bioapatite. However, studies measuring changes in stable isotope composition (Huls et al. 2010) and radiocarbon ages of experimentally burned ancient bone (Zazzo et al. 2012) demonstrate that it consists of a combination of structural carbonate, atmospheric $\mathrm{CO}_{2}$, and $\mathrm{CO}_{2}$ from the fuel of combustion. $\mathrm{CO}_{2}$ in the atmosphere of combustion is almost entirely derived from fuel, to the extent that between $67 \pm 3$ and $91 \pm 8$ percent of the carbon in calcined bone derives from that source (Zazzo et al. 2012). Thus, depending on the fuel source, radiocarbon ages of calcined bone may be subject to old wood or reservoir effects in the same manner as charcoal and collagen ages, respectively.

\section{Materials}

To investigate the accuracy of radiocarbon dates on calcined bone from archaeological sites in the Pacific Northwest, we conducted a threepart study, including two comparison sets and one set of unknowns. In one comparison set, radiocarbon ages were obtained from calcined bone and either charcoal or collagen derived from the same features in a group of six sites. These are expected to produce contemporaneous ages if the medium is appropriate. In the second series, from four additional sites, dates were compared between calcined bone and either charcoal or bone collagen derived from the same archaeological stratum within a site. These are expected to be comparable but not necessarily statistically contemporaneous. Three other sites provide test cases for dating solely with calcined bone. In each of these sites, one or more components had not been successfully radiocarbon dated due to a lack of suitable materials. In these instances, we compare the ages obtained on calcined bone with approximations based solely on cross dating by artifact styles. The three sets in our study are referred to below as the feature comparison, stratum comparison, and cross-dated unknown sets.

Archaeological contexts suitable for this investigation were selected through a survey of colleagues and perusal of archaeological reports for assemblages containing both suitably radiocarbon-dated contexts and calcined bone. Charcoal and collagen dates for the comparison sets come primarily from reports of the original excavators; calcined bone dates were conducted as part of this study. In some cases, however, we dated both the calcined bone and charcoal, or obtained additional collagen or charcoal dates to augment the radiocarbon record of a feature or site. In this paper, we use only radiocarbon ages denoted as years B.P., except when referring to age estimates based on another dating method. Calibration, while becoming standard in reporting dating results, is not relevant to this discussion because we are comparing degree of similarity in radiocarbon content rather than age per se.

\section{The Sites}

Samples come from Washington, Oregon, Idaho, and British Columbia on both sides of the Cascade Range (Figure 1). Sites east of the Cascade Range, which occupied semiarid, steppe environments, include Dry Creek, Tryon Creek, Bridge River, and 35LK1881, from Christmas Valley. Sites west of the Cascade Range lie in mesic coniferous forests and include Sequim Bypass, Tualdad Altu, Bray, Fryingpan Rockshelter, Sunrise Ridge Borrow Pit, Marymoor, Eagle Gorge Terrace, and Layser Cave. Working in two markedly distinct ecological settings increased the number of comparisons available to us and allowed us to obtain some sense of whether environment plays a part in the suitability of this medium. Soils in the western, mesic conifer forests are almost uniformly acidic; those in the eastern steppe regions are neutral to basic.

Feature Comparisons. Matching charcoal and calcined bone dates were obtained from 10 features at six sites ranging in age from the early Holocene to the mid-nineteenth century AD. Three sites, with four features, are from the dry, east side of the Cascade Range and three, 


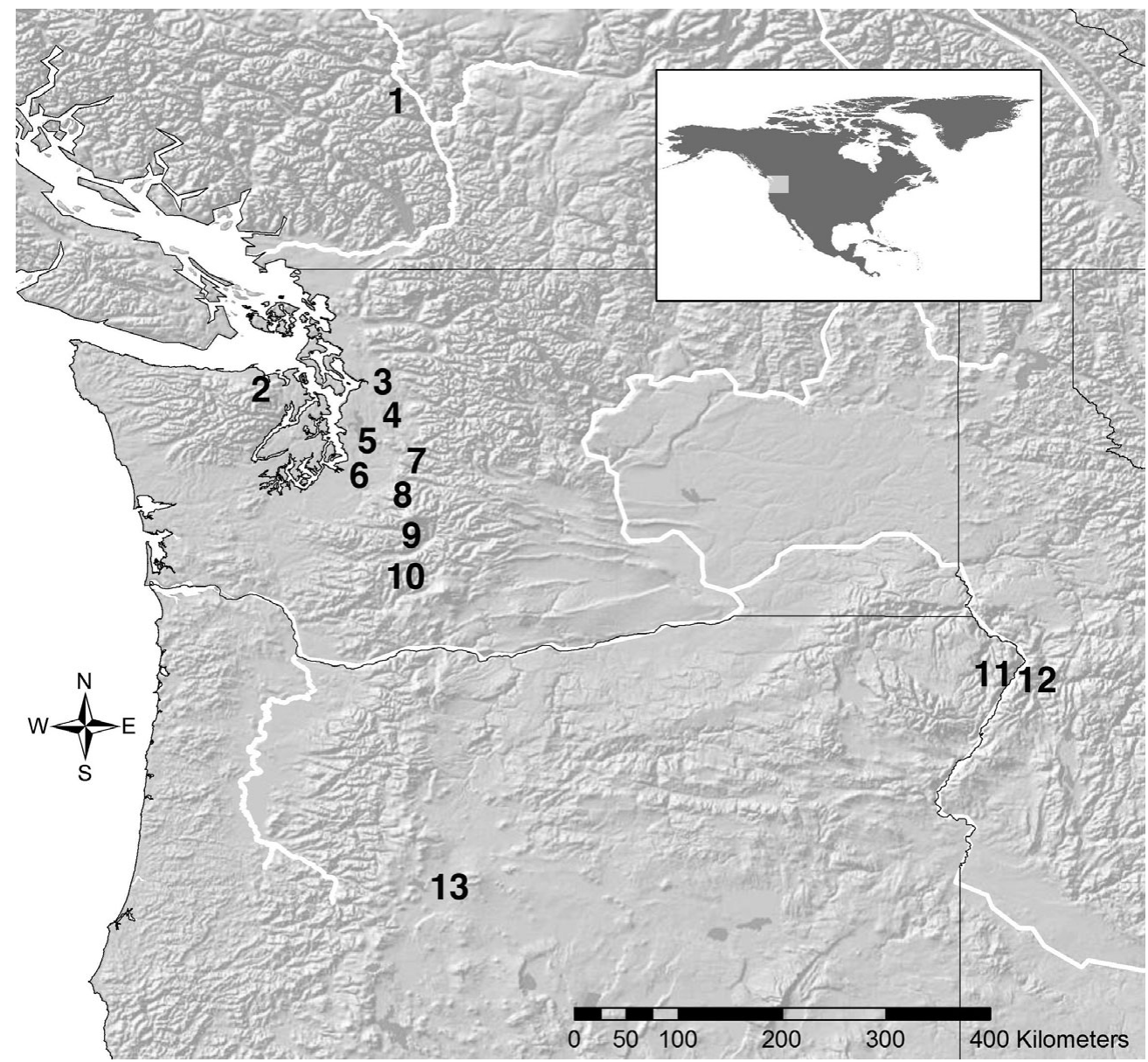

Figure 1. Map of the Pacific Northwest showing locations of sites used in this study: (1) Bridge River, (2) Sequim Bypass, (3) Biederbost, (4) Marymoor, (5) Tualdad Altu, (6) Bray, (7) Eagle Gorge Terrace, (8) Sunrise Ridge Borrow Pit, (9) Fryingpan Rockshelter, (10) Layser Cave, (11) Tryon Creek, (12) Dry Creek, 13) 35LK1881.

with the remaining six features, are from the wet, conifer-forested west side.

Bridge River (EeRi4) is a late prehistoric pithouse village on a small tributary of the Fraser River in the shrub-steppe of south-central British Columbia. The samples come from House 54, which contains 17 discrete floors dating between 1561 and 112 B.P. (Prentiss 2017; Prentiss et al. 2008). Sample pairs derive from hearth features in Floor II, which dates to the fur trade era, and Floor IIa1, which dates to $\sim 1000$ B.P. The Feature D1 sample consists of salmon bone, the only example of fish bone used in this analysis.

Fryingpan Rockshelter (45PI43) is a shallow rock overhang in the subalpine fir and hemlock forests of Mount Rainier National Park, Wash- ington. Deposits, which date between 1150 and 250 B.P., include one small fire pit (Feature 1) containing charcoal and burned bone (Lubinski and Burtchard 2005). Three radiocarbon dates are reported from the feature. Samples reported as $250 \pm 40$ (Beta-163696) for the feature "top" and $890 \pm 40$ (Beta-163698) for the "base" were AMS measurements on very small charcoal fragments. These probably represent later pit fill and sediments into which the pit was excavated, where charcoal was not abundant. A third reported date of $460 \pm 70$ (Beta-163695) from the middle of the pit was counted by liquid scintillation and therefore was much larger. It probably comes from a reported charcoal concentration and can thus be inferred to represent 
the actual fire. We therefore compare this middle date with ages of two calcined bone specimens from approximately the same depth in the feature as the charcoal concentration.

Sequim Bypass (45CA426) is a single housepit dating 2000 B.P. at the edge of a series of small prairie islands in the western hemlock forest of the northern Olympic Peninsula, Washington (Morgan 1999). Excavators determined site age using charcoal from a hearth in the house floor, a hearth that also contained burned mammal bone used in this study.

Sunrise Ridge Borrow Pit (45PI408) is a set of briefly occupied campsites on a broad bench in the western hemlock-forested northeast slope of Mount Rainier, dating between $\sim 2600$ and 1600 B.P. (McCutcheon and Dampf 2002; McCutcheon et al. 2017). Multiple small, spatially distinct concentrations of lithics, firemodified rock (FMR), calcined bone, and charcoal were stratified between thick deposits of volcanic tephra. We compared charcoal and calcined bone ages from four hearth-like features found in these concentrations. One of these, listed here as Feature $\mathrm{H} / \mathrm{I} / \mathrm{J}$, was a close grouping of spatially overlapping artifact concentrations that can be considered a single feature for purposes of this analysis. In this case, with the exception of one estimate from Beta Analytic, all charcoal dates used in feature comparisons for Sunrise Ridge Borrow Pit were obtained as part of this study.

Dry Creek (10IH13) is a lightly utilized set of late prehistoric housepits on a dry alluvial fan in the steppe zone of Hells Canyon, Idaho. House 1, the most extensively excavated of the housepits, had been occupied only briefly around 1400 B.P., when it burned and was permanently abandoned (Chatters 1994). Trenching of the house wall revealed it had been originally dug through a very poorly represented earlier occupation. Radiocarbon ages on charcoal for this house come from slender roof stringers that had collapsed onto the sandy floor from which excavators obtained calcined bones. We dated one additional burned stringer as part of this study to corroborate the original age estimate.

35LK1881 is one of two early Holocene sites in the arid Christmas Valley of southcentral Oregon that contain large, shallow basin features filled with bits of charcoal and massive amounts of rabbit bone (Oetting 1994). Dates on sagebrush and shadescale charcoal from this site's single feature range between $\sim 9100$ and 8100 B.P. Although most of the bone was unburned, we were able to find one calcined jackrabbit (Lepus sp.) long bone, large enough for dating. We also obtained a date on collagen from unburned rabbit bone found in the feature. This site was selected specifically to extend our comparison into the early Holocene.

Stratigraphic Comparisons. We were able to obtain comparisons for seven stratigraphic units, which in some cases amounted to complete midden deposits, from four sites. All four are located in the forested regions of western Washington and range in radiocarbon age from the second to seventh millennium B.P.

Tualdad Altu (45KI59) is a stratified village midden from a low-elevation riverine setting in a western red cedar-dominated forest near Washington's Puget Sound, dated originally to the late Marpole Phase in the Gulf of Georgia sequence (Chatters et al. 1990). The site was excavated stratigraphically as four cultural units (CU). Radiocarbon dates obtained on charcoal from the upper three CUs, I through III, exhibited no stratigraphic progression, a finding attributed to the old-wood effect. We obtained calcined bone ages from all four CUs and added a collagen date from CU II to add another conventional age to the comparison. This enabled us to also consider the stratigraphic consistency among dates obtained from calcined bone.

Biederbost (45SN100) is a village midden and associated wet site located in the western red cedar forests along the Snoqualmie River of lowland western Washington. The Washington Archaeological Society excavated the site, obtaining a date of $1940 \pm 80$ B.P. on charcoal from the wet part of the site (Nelson 1976), which places it in the Marpole Phase of the Gulf of Georgia sequence (Matson and Coupland 1995). During reanalysis, Rorabaugh (2015) obtained additional dates on charcoal and bone from both parts of the site. Samples from the wet portion dated $1670 \pm 29$ B.P. and $2070 \pm 40$ B.P. and those from the dry portion, taken from post molds beneath the midden, $2010 \pm 30$ and 
$2182 \pm 30$ B.P. Samples used in this analysis derive from a midden that overlays Rorabaugh's (2015) dry site samples and should thus be expected to postdate them.

Bray (45PI1276) is a single-component, plant-processing site in the western hemlock forest overlooking the White River valley in lowland western Washington. Projectile point and bead styles, along with two radiocarbon dates on bark charcoal from earth ovens, place this site in the later Locarno Beach Phase of the Gulf of Georgia sequence (Chatters and Fairbanks 2013; Matson and Coupland 1995). Calcined bone specimens used in this analysis come from the same excavation units and arbitrary levels as the dated earth ovens.

Layser Cave (45LE223) is a small lava tube in the western hemlock forest on the western flank of Washington's Cascade Range. It contained stratified deposits of tephra and angular basalt rich in mammal bone and hunting-associated artifacts dating to the middle Holocene (Daugherty et al. 1987). Cultural materials were concentrated in Strata VIII through XII and were initially radiocarbon dated between approximately 7000 and 4800 B.P. Careful reading of the site report reveals that stratigraphic excavation was difficult, but that the excavators could most easily discern Strata IX through XI; our analysis focused on these strata. We dated calcined bone from a concentration in Stratum $\mathrm{X}$ that may have been associated with Feature 1, from which charcoal had also been dated. After finding a larger disparity between these measurements than was seen in most other comparisons, we also radiocarbon dated collagen from Strata IX and XI in an attempt to clarify the radiocarbon chronology of the site. Like 35LK1881, we included this site in the study to add greater time depth to the analysis, despite its limitations.

Cross-Reference Unknowns. The following three sites had not previously been successfully radiocarbon dated. Age estimates against which we compare the calcined bone radiocarbon ages from these sites are based on artifact style and geologic context. Two of the sites are from mesic conifer forest environments and one from a steppe region. In all, four components were targeted for radiocarbon age estimation.
Eagle Gorge Terrace (45KI1083) is a late prehistoric hunting camp in the western hemlock forest of the lower Cascade Range of western Washington. The site is an essentially surficial (0-30 cm deep) concentration of fire-modified rock, calcined bone, and lithic tools that are similar stylistically to CU 1 at Tualdad Altu (Chatters and Cooper 2016; Cooper 2012). Charcoal was abundant, but evidence for recent forest fires negated a confident association with human occupation. An $865 \pm 30$ B.P. date obtained on charred bone was considered too young, given the close stylistic similarity of this site to Tualdad Altu. Three specimens of calcined large mammal long bone were dated for this analysis to establish a more accurate age for the assemblage.

Marymoor (45KI9) is one of the first archaeological sites to be intensively excavated in the Puget Lowland of western Washington. Located in what would have historically been a riverine western red cedar forest, the site appeared to have been occupied through much of the middle and later Holocene, with artifacts ranging from serrated foliate projectile points of Butler's (1961) Old Cordilleran Culture to large corner-notched projectile points generally associated with the late Holocene (Greengo and Houston 1970). We obtained calcined bone from the two deepest (and the only apparently intact) layers, identified as Strata 6 and 7, in the geologically stratified portion of the site. Reanalysis of the artifact assemblage from excavation units containing these strata revealed that projectile points from Stratum 7 consisted solely of serrated-edged and unserrated foliates, whereas those from Stratum 6 included only unserrated foliates and large side-notched forms (Brown and Chatters 2016). The Stratum 7 assemblage resembles those from the nearby Granite Falls site group. This group has been dated by luminescence methods (and here converted to a radiocarbon time scale) to between $9120 \pm 570$ and $7520 \pm 390 \mathrm{cal}$ B.P. (equivalent at $1 \sigma$ to $\sim 8700-6300$ B.P.; Chatters et al. 2011) and in the Early Cascade Phase of eastern Washington to between 8000 and 6850 B.P. (Bense 1972). No radiocarbon dates have yet been obtained for this material in western Washington. The assemblage found in Stratum 6 has not previously been dated in western Washington, but similar side-notched projectile point 
forms are a hallmark of the Late Cascade Phase of eastern Washington and typically date between 6000 and 4000 B.P. (Lohse and Schou 2008). Bone used in this analysis was obtained from arbitrary levels attributable to individual geologic strata through study of excavation profiles.

Tryon Creek (35WA288) is a stratified open site overlooking the Snake River in the shrub steppe zone of Hells Canyon, Oregon. The upper terrace of the site includes a single, large house pit dug into stony colluvium, which overlies a thick body of eolian silt (loess) that produced a large foliate biface and abundant bifacialreduction debitage of distinctive multicolored chert (Hackenberger and Thompson 1995). Charcoal could not be securely associated with the deeper assemblage, so it remained undated. However, similar artifact assemblages have been found in strata of loess and eolian sand elsewhere in Hells Canyon, where they date between circa 6000 and 8000 B.P. (Randolph and Dahlstrom 1977; Reid and Chatters 1997). We tested associated calcined bone from three superimposed levels in the uppermost two loess strata to obtain a radiometric age for the assemblage and to test calcined bone dates for stratigraphic consistency.

\section{Methods}

After identifying suitable sites, strata, and features from excavation reports, we selected samples of calcined bone from collections archived at the Burke Museum of Natural History and Culture, Oregon Museum of Nature and Culture, Mount Rainier National Park, Gifford Pinchot National Forest, University of Montana, University of Idaho, and Central Washington University. Bone suitable for dating must have the enlarged, closely packed crystals and low carbonate fraction of material burned at or above $650^{\circ} \mathrm{C}$. For maximum success in selecting samples, it is advisable to use XRD or FTIR to assess the crystallinity of the samples. Stable isotope analysis has also been used to determine the origin of the carbon within the carbonate of a sample. Because calcined bone consists largely of carbon from the fuel source, the $\delta^{13} \mathrm{C}$ is expected to be consistent with primarily a plant rather than an animal source. FTIR, XRD, and stable isotope analysis are costly procedures, however, and may not be readily available to chronically budgetlimited archaeologists. Therefore, in this proof of concept research, we selected samples strictly on bone color to most closely match conditions encountered by the majority of researchers. We snapped candidate specimens with pure white outer surfaces to allow inspection of internal coloration, using only those that were white throughout or graded from white to light blue. Where possible, we selected thick cortical bone from long bone shafts as having the greatest probable density and lowest ratio of surface area to volume (Figure 2). This reduced the probability of diagenetic contamination by precipitation of secondary carbonates.

We conducted sample pretreatment and analysis at DirectAMS laboratories. Pretreatment of calcined bone generally followed Lanting and colleagues (2001), with minor revisions. We first cleaned specimens with a scalpel or rotary burr to remove surface contaminants and reduce the amount of secondary calcite, which is expected to be greater on outer bone surfaces. This step could not be fully executed with calcined fish bone from Bridge River or the thin cortical rabbit long bone from 35LK1881 without eliminating the samples altogether. After cleaning, we placed specimens in borosilicate glass test tubes, soaked them in 3 percent hydrogen peroxide for 24 hours at $20^{\circ} \mathrm{C}$ to remove organic contaminants, rinsed them three times in deionized water, dried, and weighed them. After breaking samples into fragments less than $5 \mathrm{~mm}$ in diameter, we inspected them to remove any fragments that were not pure white to light blue, and finally soaked them in $1 \mathrm{~N}$ acetic acid for 24 hours at $20^{\circ} \mathrm{C}$ to dissolve secondary calcite. We again rinsed them in three exchanges of deionized water and oven-dried them at $90^{\circ} \mathrm{C}$ overnight to evaporate any remaining acetic acid. We crushed 300 to $400 \mathrm{mg}$ of each sample and digested it in an evacuated $10 \mathrm{ml}$ Vacutainer ${ }^{\mathrm{TM}}$ brand septumstoppered tube with $4 \mathrm{ml}$ of orthophosphoric acid. We isolated the resultant $\mathrm{CO}_{2}$ and reduced it to graphite using a sealed-tube zinc-reduction method (Ognibene et al. 2003) and measured it in an NEC Pelletron 500kv accelerator mass spectrometer. We processed charcoal according to a standard acid-base-acid protocol adapted from Taylor (1987). Collagen dates are based on 


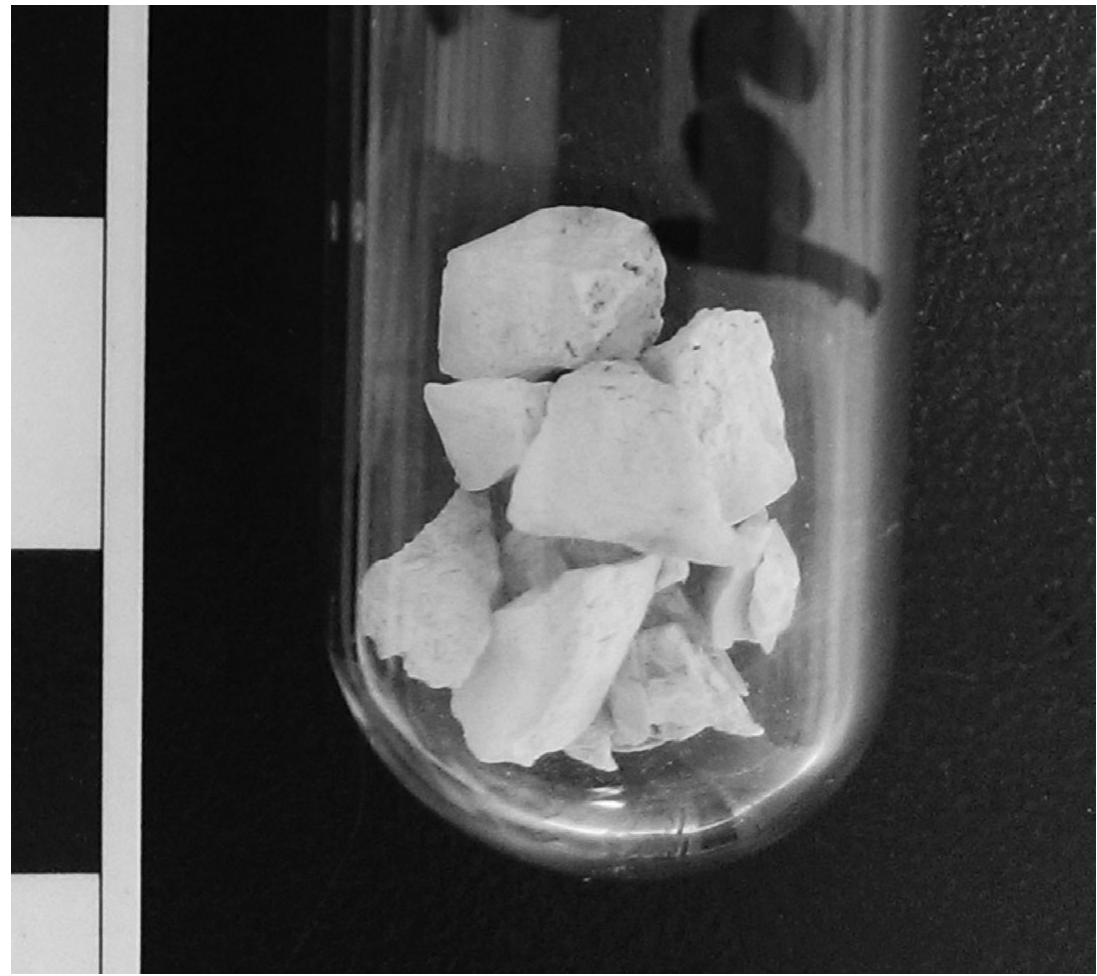

Figure 2. Bone in a calcined state suitable for radiocarbon dating, shown following peroxide treatment. Scale at left is in centimeters.

filtered (not ultrafiltered) gelatin extracted following Stafford and colleagues (1991).

Of the 43 measured samples of calcined bone, plus an additional four duplicates, all but three produced sufficient ion current for an age estimate. Samples that produced weak current but still produced sufficient readings for age estimation were remeasured, where possible, to obtain higher precision. Subsequent to completing this study, we have determined that, for best results, more than $500 \mathrm{mg}$ of pretreated material (producing $\sim 500$ micrograms of carbon) is optimal.

\section{Results and Discussion}

Comparisons between calcined and conventional ages are presented in Tables 1-3. Expectations are somewhat different among the comparison sets. In comparing the feature set, we expect the ages of conventional materials and calcined bone to be contemporaneous if calcined bone is an accurate medium for radiocarbon dating. Therefore, for that dataset we conduct a $t$ test of contemporaneity (Long and Rippeteau 1974), pairing each date on calcined bone with each date on conventional material from each feature, as seen in the two far-right columns of Table 1. If a calcined bone date is compared with more than one charcoal date in the table, as occurs in Sunrise Ridge Borrow Pit features AA and $\mathrm{H} / \mathrm{I} / \mathrm{J}$ and in Dry Creek, the conventional ages are repeated to facilitate interpretation of the results. Dates are considered contemporaneous if their $p$ value at infinite degrees of freedom is greater than 0.05 . For the stratigraphic comparisons, we do not expect contemporaneity, but rather for the results from calcined bone to be comparable with those from other media; that is, to be within the same age range as, or to be stratigraphically consistent with, other results. Therefore, no statistical comparison is appropriate. Finally, in the set of cross-dating unknowns we expect only for the results to fall within the age range based on the associated artifact assemblage.

It is important in the feature comparison to keep in mind the differences in the origins of 
Table 1. Feature Comparison of Calcined Bone and Conventional Media Radiocarbon Ages.

\begin{tabular}{|c|c|c|c|c|c|c|c|}
\hline Site & Feature & $\begin{array}{l}\text { Calcined } \\
\text { Bone }\end{array}$ & Lab Number & $\begin{array}{c}\text { Charcoal or } \\
\text { Collagen }\end{array}$ & Lab Number & $t$ & $p>0.05$ \\
\hline \multirow[t]{2}{*}{ Bridge River } & HP54/D1 & $\begin{array}{c}500 \pm 26 \\
(114 \pm 26)^{\mathrm{a}}\end{array}$ & D-AMS 3591 & $112 \pm 25$ & D-AMS $3801^{\mathrm{b}}$ & $\begin{array}{l}10.78 \\
(0.055)^{\mathrm{a}}\end{array}$ & $\begin{array}{c}\mathrm{N} \\
(\mathrm{Y})^{\mathrm{a}}\end{array}$ \\
\hline & HP54/D2 & $\begin{array}{c}1425 \pm 26 \\
(1039 \pm 26)^{\mathrm{a}}\end{array}$ & D-AMS 3593 & $1047 \pm 31$ & D-AMS $2804^{b}$ & $\begin{array}{l}9.34 \\
(0.198)^{\mathrm{a}}\end{array}$ & $\begin{array}{c}\mathrm{N} \\
(\mathrm{Y})^{\mathrm{a}}\end{array}$ \\
\hline \multirow{2}{*}{$\begin{array}{l}\text { Fryingpan } \\
\text { Rockshelter }\end{array}$} & 1 & $480 \pm 32^{\mathrm{c}}$ & D-AMS 3819 & $460 \pm 70$ & Beta- $163695^{\mathrm{d}}$ & 0.260 & $\mathrm{Y}$ \\
\hline & & $578 \pm 26$ & D-AMS 3818 & $460 \pm 70$ & Beta- $163695^{d}$ & 1.580 & Y \\
\hline \multirow[t]{4}{*}{ Dry Creek } & HP1, floor & $1389 \pm 26$ & D-AMS 3282 & $1405 \pm 45$ & AA- $23390^{\mathrm{e}}$ & 0.308 & $\mathrm{Y}$ \\
\hline & & & & $1342 \pm 32$ & D-AMS 4799 & 1.140 & $\mathrm{Y}$ \\
\hline & & $3027 \pm 28$ & D-AMS 3281 & $1342 \pm 32$ & D-AMS 4799 & 40.87 & $\mathrm{~N}$ \\
\hline & & & & $1405 \pm 45$ & AA- $23390^{\mathrm{e}}$ & 31.21 & $\mathrm{~N}$ \\
\hline \multirow{8}{*}{$\begin{array}{c}\text { Sunrise Ridge } \\
\text { Borrow Pit }\end{array}$} & AA & $2246 \pm 24$ & D-AMS 3594 & $2410 \pm 28$ & D-AMS 3596 & 4.447 & $\mathrm{~N}$ \\
\hline & & & & $2286 \pm 43$ & D-AMS 3598 & 0.812 & $\mathrm{Y}$ \\
\hline & & $2265 \pm 27$ & D-AMS 3597 & $2286 \pm 43$ & D-AMS 3598 & 0.414 & $\mathrm{Y}$ \\
\hline & & & & $2410 \pm 28$ & D-AMS 3596 & 3.728 & $\mathrm{~N}$ \\
\hline & $\mathrm{AD}$ & $2484 \pm 31$ & D-AMS 11249 & $2583 \pm 33$ & D-AMS 4801 & 1.745 & $\mathrm{~N}$ \\
\hline & $\mathrm{R}$ & $1683 \pm 42$ & D-AMS 4802 & $1652 \pm 32$ & D-AMS 4800 & 0.587 & $\mathrm{Y}$ \\
\hline & $\mathrm{H} / \mathrm{I} / \mathrm{J}$ & $2574 \pm 29$ & D-AMS 7918 & $2576 \pm 26$ & D-AMS 7913 & 0.051 & $\mathrm{Y}$ \\
\hline & & & & $2390 \pm 80$ & Beta- $120520^{\text {f }}$ & 2.162 & $\mathrm{~N}$ \\
\hline \multirow[t]{2}{*}{ Sequim Bypass } & 418 & $2425 \pm 25$ & D-AMS-14290 & $2480 \pm 50$ & Beta-107612 ${ }^{\mathrm{g}}$ & 0.984 & $\mathrm{Y}$ \\
\hline & & $2489 \pm 28$ & D-AMS-14291 & $2480 \pm 50$ & Beta-107612 & 0.157 & $\mathrm{Y}$ \\
\hline \multirow[t]{5}{*}{ 35LK1881 } & 1 & $8331 \pm 36$ & D-AMS-11250 & $8680 \pm 40$ & D-AMS $11251^{\mathrm{h}}$ & 6.485 & $\mathrm{~N}$ \\
\hline & & & & $8080 \pm 120$ & Beta-22579i & 2.003 & $\mathrm{~N}$ \\
\hline & & & & $8880 \pm 120$ & Beta-30340 & 4.382 & $\mathrm{~N}$ \\
\hline & & & & $9120 \pm 120$ & Beta-30341 ${ }^{\mathrm{i}}$ & 6.298 & $\mathrm{~N}$ \\
\hline & & & & $8950 \pm 120$ & Beta-30342 ${ }^{\mathrm{i}}$ & 4.941 & $\mathrm{~N}$ \\
\hline
\end{tabular}

${ }^{\text {a }}$ Reservoir corrected; ${ }^{b}$ Prentiss 2017:62; ${ }^{\mathrm{c}}$ average of two measurements; ${ }^{\mathrm{d}}$ Lubinski and Burtchard 2005:40; ${ }^{\mathrm{e}}$ Chatters 1994;

${ }^{\mathrm{f}}$ McCutcheon and Dampf 2002:33; ${ }^{\mathrm{g}}$ Morgan 1999:117; ${ }^{\mathrm{h}}$ on collagen; ${ }^{\mathrm{i}}$ Oetting 1994:334.

Table 2. Stratigraphic Comparison of Calcined Bone and Conventional Media Radiocarbon Ages.

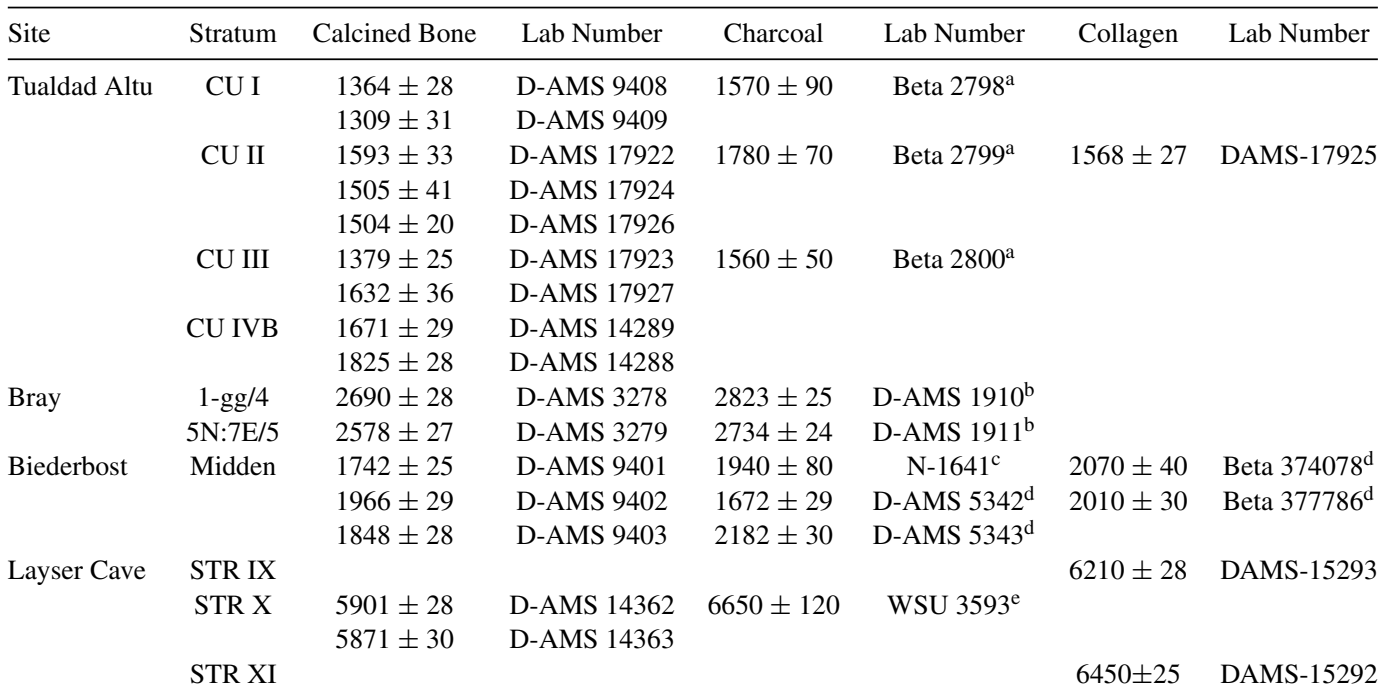

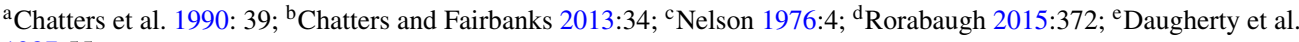
1987:55. 
Table 3. Calcined Bone Dating of Cross-Dated Assemblages.

\begin{tabular}{|c|c|c|c|c|c|c|}
\hline Site & Unit & Level & Stratum & $\begin{array}{c}\text { Estimated } \\
{ }^{14} \mathrm{C} \text { Age B.P. }\end{array}$ & $\begin{array}{l}\text { Calcined } \\
\text { Bone B.P. }\end{array}$ & Lab Number \\
\hline \multirow[t]{3}{*}{ Eagle Gorge } & TU7 & 1 & & $1000-1600$ & $1179 \pm 27$ & D-AMS 3275 \\
\hline & TU8 & 3 & & $1000-1600$ & $1308 \pm 41^{\mathrm{a}}$ & D-AMS 3276 \\
\hline & TU9 & 3 & & $1000-1600$ & $1272 \pm 38^{\mathrm{a}}$ & D-AMS 3277 \\
\hline \multirow[t]{4}{*}{ Marymoor } & $24 \mathrm{~S} / 6 \mathrm{E}$ & $60-80 \mathrm{~cm}(\mathrm{bd})$ & Str 6 & $4000-6000$ & $5290 \pm 33$ & D-AMS 9404 \\
\hline & $24 \mathrm{~S} / 3 \mathrm{~W}$ & $40-60 \mathrm{~cm}(\mathrm{bd})$ & Str 6 & $4000-6000$ & $5475 \pm 35$ & D-AMS 9407 \\
\hline & $24 \mathrm{~S} / 6 \mathrm{E}$ & $80-100 \mathrm{~cm}(\mathrm{bd})$ & Str 7 & $6300-8700$ & $5972 \pm 34$ & D-AMS 9405 \\
\hline & 21S3W & $80-100 \mathrm{~cm}(\mathrm{bd})$ & Str 7 & $6300-8700$ & $7172 \pm 31$ & D-AMS 9406 \\
\hline \multirow[t]{3}{*}{ Tryon Creek } & Unit F N64/E66 & 14 & & $6000-8000$ & $6976 \pm 36$ & D-AMS 3642 \\
\hline & Unit F N64/E66 & 15 & & $6000-8000$ & $7695 \pm 46$ & D-AMS 3640 \\
\hline & Unit F N64/E66 & 16 & & $6000-8000$ & $7603 \pm 39$ & D-AMS 3641 \\
\hline
\end{tabular}

${ }^{a}$ Average of two measurements.

carbon from charcoal and collagen on the one hand and calcined bone on the other. The carbon in collagen and wood charcoal, particularly when the latter is a small amount from a single plant, as is typically selected for AMS dating, represents brief intervals of time-no more than a few years in either case. Carbon in calcined bone, on the other hand, is an unknown combination of the structural carbon in the bone plus fuel materials, which may include other animal tissues, and multiple pieces of wood with different ages. Thus, we do not expect the ages of charcoal and calcined bone, even from a single feature, to be identical.

\section{Feature Comparisons}

We find that at least one calcined bone date is contemporaneous with at least one of the charcoal ages from the same feature in six of 10 feature contexts, including Fryingpan Rockshelter, Dry Creek, Sequim Bypass, and three of the four features at Sunrise Ridge Borrow Pit (Table 1). The two media sometimes produce ages within a decade or two of each other. In two features at the Sunrise Ridge Borrow Pit, AA and $\mathrm{H} / \mathrm{I} / \mathrm{J}$, calcined bone results are contemporaneous with one of the two charcoal dates from the same feature, but not with the other. However, in those cases the charcoal ages themselves fail the test of contemporaneity (AA, $t=2.414$, $p<0.01 ; \mathrm{H} / \mathrm{I} / \mathrm{J}, t=2.417, p<0.02)$ but in no case do any of the age estimates fall outside two standard errors of each other. We consider these calcined bone ages to be contemporaneous with the conventional results. In Feature AD in the same site, the two ages fail the test of contemporaneity, but ages are only $\sim 100$ years apart, and their distributions also overlap within $2 \sigma$. This again is an acceptable, if weaker, match. Four instances however, including those from Bridge River and 35LK1881, and one result from Dry Creek, exhibit wider deviations and warrant closer consideration.

In both features from Bridge River House 54, calcined bone dates are nearly 400 years older than directly associated charcoal. Interestingly, this difference is an almost precise match to the $386 \pm 73$ year marine reservoir effect calculated by Prentiss (2017) for salmon remains from the site. Sample D-AMS 3592 is in fact salmon bone and may have burned in a self-fueled fire. It is not unusual to see hearths packed with sandsized shards of salmon bone in houses along the northwest coast (e.g., Chatters et al. 1990). If the marine reservoir effect were subtracted from the radiocarbon age of this sample, the mean estimated age would be 114 B.P., which is virtually identical to the charcoal age of $112 \pm 25$ B.P. The same is true for D-AMS 3593, for which the same computation would result in an age of 1039 B.P. again virtually identical with the charcoal age of $1047 \pm 31$. The existence of a marine reservoir effect in the fuel, perhaps fish bone or fish fat, or in the animal from which the bone came may explain these apparent age differences. Dog was a common food item at Bridge River, and stable isotope study of dog bone from the site indicates that these animals lived primarily on salmon (Diaz et al. 2017), strongly supporting this suggestion. Therefore, we use the reservoir corrected ages of 


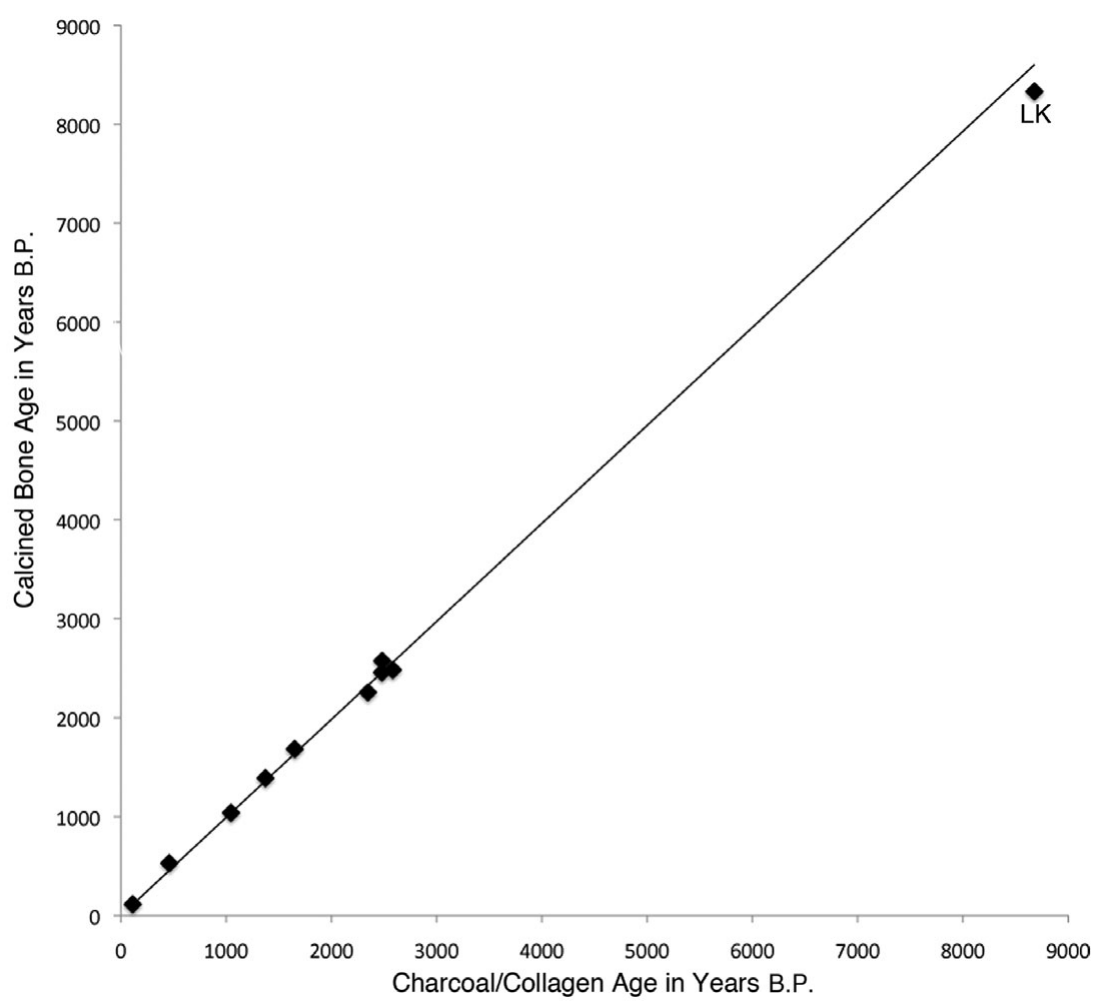

Figure 3. Comparison of radiocarbon ages produced from calcined bone with charcoal or collagen results from 10 feature contexts, shown against a line representing identity. Values are reservoir corrected and where multiple dates exist for a material type, averaged; exception is $35 \mathrm{LK} 1881(\mathrm{LK})$, for which only the collagen age is presented.

these dates in Table 1 and a graphic comparison below.

For 35LK1881, the calcined bone age of $8331 \pm 36$ falls within the range of radiocarbon ages obtained on charcoal and rabbit bone collagen, which is not in itself troubling. However, the disparity in ages between the burned and unburned bone $i s$ troubling, particularly when the calcined age is nearly 300 years younger. Old fuel wood cannot explain a younger age. As mentioned in the methods section, we were unable to vigorously remove the surface of this millimeterthin cortical bone without reducing the sample to unusable size, leaving open the possibility of contamination by secondary carbonates. In this instance, unsuccessful removal of diagenetic carbonates formed from dissolved atmospheric $\mathrm{CO}_{2}$, which would be younger than the carbonate trapped in hydroxyapatite crystals, is the likely culprit. In graphic treatments of this comparison, we use the collagen age as the conventional control because it is more likely to represent the actual age of the rabbit-cooking event.

The situation is simpler for sample D-AMS 3027 from the house floor at Dry Creek, which shows the greatest deviation of all at around 1,600 years and is the only sample among the feature comparison group that would not provide an acceptable age estimate. In this instance, the bone fragment in question probably comes from the older component of the site, which was intersected by construction of the pithouse. This anomalous result is not included in the following graphic treatment.

Figure 3 provides an illustration of the nearidentity of the calcined versus conventional age estimates we obtained from single features. Displayed there are the average age estimates from calcined bone (if more than one obtained) compared with the average age estimates from charcoal (if more than one exists). As noted above, Bridge River values are presented as reservoir 
corrected and 35LK1881 (LK) is a comparison with the collagen age only. The wildly divergent Dry Creek estimate is excluded because it would be discounted in any archaeological analysis. The correlation between the two measures is almost perfect, as shown in the comparison between the distribution of values and the 1:1 correlation line. A linear equation of this relationship forced to the origin produces an $R^{2}$ of 0.9982 . Leaving the anomalous Dry Creek value in the series only reduces the correlation to 0.9368 . The broad gap between the 35LK1881 date (LK) and other findings does not drive the correlation, for without it the $R^{2}$ is still 0.9952 .

\section{Stratigraphic Comparisons}

Similar results are seen in comparisons between calcined bone and the collagen or charcoal ages from the same stratigraphic context (Table 2). For Biederbost and Bray, calcined bone estimates fall within 100 years of other dates from the same context. The Biederbost calcined samples, which come from within a midden deposit, are appropriately somewhat younger than materials from the base of the midden. Calcined bone dates do, however, fall within the range of all charcoal ages from the site. Calcined bone from Layser Cave is over 700 years younger than charcoal from the same Stratum X, but collagen ages from strata purportedly above and below Stratum X are much closer in age, highlighting problems of stratigraphic integrity in this site. It is informative that two samples of calcined bone from Stratum $\mathrm{X}$ are contemporaneous with each other $(t=0.79$, $p>0.20$ ), suggesting this material may be giving more consistent results than the other materials from the site.

This observation also holds for specimens from Tualdad Altu. Charcoal dates originally obtained for the site by liquid scintillation counting exhibit no stratigraphic patterning, with the youngest near the bottom (CU III) and oldest at the midpoint. This was attributed to the old wood effect. As with other examples, however, calcined bone and conventional materials provide similar age estimates. But in this instance, the calcined bone can be seen to provide a more acceptable pattern of increasing age with depth (Figure 4). Ages steadily decrease from $1825 \pm$
28 and $1671 \pm 29$ B.P. in CU IVb to $1364 \pm 28$ and $1309 \pm 31$ B.P. in CU I. Notably, the single collagen age we obtained in CU II falls precisely within the age range of calcined bone from the same stratum and both are stratigraphically consistent with overlying and underlying strata.

One exception disrupts this tidy sequence and serves to emphasize the suitability of calcined bone as a dating medium. Sample D-AMS 17923, a bone fragment placed analytically into CU III, has an age of $1379 \pm 25$ B.P., which is more appropriate for CU I. After obtaining this finding, we rechecked the original field notes for the excavation unit of origin, which was situated near the thinning edge of the midden (Chatters 1980). The excavator expressed frustration at the difficulty of following stratigraphic boundaries in attenuated strata and noted a large krotovina in the grid square from which the specimen had come. Bioturbation and/or excavator error may account for the age disparity. This observation both highlights the importance of carefully researching candidate samples for radiocarbon dating and demonstrates the accuracy of calcined bone dating.

\section{Cross-Dated Unknowns}

This group of test samples addresses archaeological components that have not heretofore been successfully radiocarbon dated. In Table 3 , we provide age estimates based on artifact crossdating for comparison with the calcined bone ages. Two sites, Tryon Creek and Marymoor, each contain two superimposed, undated components. In each case, the calcined bone produces radiocarbon ages that fall within the expected age range. Eagle Gorge Terrace, with an assemblage closely resembling that from CU I at Tualdad Altu, appropriately dates to within 100 years of that cultural unit. At Marymoor, Stratum 6 dates between $\sim 5300$ and 5500 B.P., precisely within the posited range. Stratum 7 ranges from well within to approximately 300 years younger than the anticipated age range, but keep in mind no radiocarbon age had previously been obtained for either of these assemblages. Finally, the Tryon Creek samples date well within the 6000-8000 B.P. age estimate and tend, although imperfectly, to be progressively older with depth. 


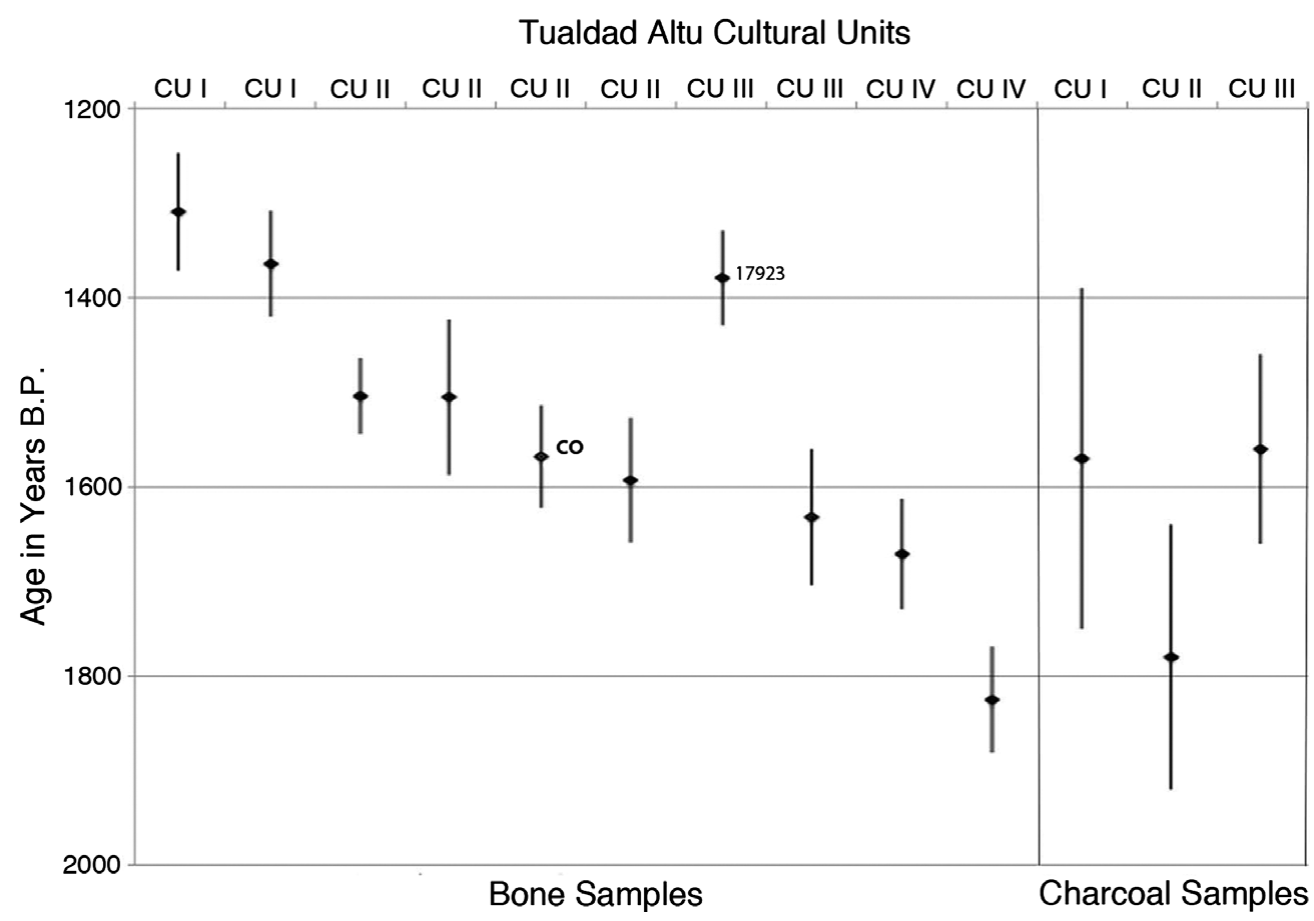

Figure 4. Stratigraphic progression of radiocarbon dates on bone (left) and charcoal from Tualdad Altu. CO marks the single collagen sample; 17923 is the DirectAMS number of the one nonconforming estimate based on calcined bone.

\section{Effects of Environment and Age}

Samples in this analysis come from markedly different ecological and edaphic settings and range from the early Holocene to postcolonial times. As a result, some observations are possible regarding the influence of environment and time on the accuracy of calcined bone ages, as determined from their relationship to ages based on more conventional media. When the reservoir effect is taken into account for Bridge River and the one wildly anomalous sample from Dry Creek is removed, pairings from conifer forest and steppe environment perform equally well as seen in the almost perfect 1:1 correlation displayed in Figure 3 and the paired $t$ values in Table 1 . The same is true for the cross-dated unknowns, which in all cases produced expected and stratigraphically consistent results, regardless of their ecological situation. If anything, calcined bone from the more mesic settings produces results that more closely match the associated charcoal and/or collagen (Table 1). This could be due to acidic soils limiting precipitation of secondary calcite among the calcined hydroxyapatite crystals.

The effect of age is less apparent because only two of the test pairings, 35LK1881 and Layser Cave, are more than 3,000 years old. As seen in Tables 1 and 2 and in Figure 3, there is an apparent tendency for calcined bone to produce younger dates than expected as we move farther back in time. At 35LK1881, calcined jackrabbit bone, although it fell within the broad range of ages for charcoal, dated $\sim 350$ years younger than bone collagen from the same species, which we consider to provide the most reliable age estimate for the feature. For Layser Cave, calcined bone was also on the order of 300 years younger than collagen, although the stratigraphic relationships between the samples are somewhat uncertain. This divergence among older samples may be limited to our small sample set. Surovell and colleagues (2016), for example, obtained calcined bone ages on Folsom material from the Hanson Site that were not younger than expected but rather fell at the older end of the range of 
dates based on collagen. Calcined bone also performed well on unknown test cases dating to the middle and early Holocene in the present study. These findings and the results obtained by Surovell and colleagues (2016) indicate there is no systematic age-related tendency for early Holocene or older samples of calcined bone to yield dates that are younger than expected. The fact that the more ancient calcined bone samples in our study trend younger than their conventional counterparts but not uniformly suggests that the problem lies in pretreatment procedures. It is possible that secondary calcite, which we would expect to build up with increasing age, can become more resistant to acetic acid removal with time. As noted above, we were unable to remove the outer surface of the rabbit bone from 35LK1881, making residual secondary calcite a likely explanation. Therefore, it is advisable to extend the acetic acid leeching step and/or conduct it under vacuum to ensure more complete removal of this contaminant. It is also possible that in some settings isotopic exchange takes place between dissolved carbonate and carbonate formed within the hydroxyapatite crystals themselves, although this is unlikely in the large, regular, tightly spaced crystals formed by calcination. More comparisons of older samples are needed, with a range of pretreatment protocols, before this issue can be fully resolved.

\section{Conclusion}

Calcined bone, when selected solely on the basis of visual characteristics, is as reliable a medium for radiocarbon dating as charcoal or collagen. When paired with charcoal or bone collagen from the same features or geologic strata, it produces almost uniformly comparable results and can provide radiocarbon ages in contexts where more traditional media are either unavailable or unreliable due to environmental circumstances. Whether the material comes from a mesic environment with acidic soils or an arid landscape prone to formation of calcic soil horizons seems to make little or no difference. This medium has its limitations like any other, being subject to both the old wood and marine reservoir effects. Calcined bone can, however, be more reliable than charcoal in some cases, owing to the fact that the tiny amount of carbon it contains represents a mixture of atoms from disparate fuel sources as well as the bone mineral itself, diminishing these disrupting influences. In settings like the conifer forests of the Pacific Northwest of North America, where acidic soils destroy bone and ubiquitous fire confuses the meaning of charcoal, or in the hot deserts of the subtropics, where collagen does not survive, it can be the only medium of cultural origin available for the application of the radiocarbon dating method.

Acknowledgments. Special thanks for assistance accessing collections to Laura Phillips of the Burke Museum (Tualdad Altu), Pam Endzweig of the Oregon Museum of Nature and Culture (35LK1881), Greg Burtchard formerly of the National Park Service (Fryingpan Rockshelter), Rick McClure formerly of the U.S. Forest Service (Layser Cave), Lawr Salo formerly of the U.S. Army Corps of Engineers (Eagle Gorge Terrace), and Anna Prentiss of the University of Montana (Bridge River). AMS dating was provided by DirectAMS, a division of Accium Biosciences, Seattle, Washington. This paper benefited from comments and observations by Jason Giacomo and three anonymous reviewers.

Data Availability Statement. All data used in and resulting from this study are provided herein.

\section{References Cited}

Bense, Judith A.

1972 The Cascade Phase: A Study in the Effects of the Altithermal on a Cultural System. Unpublished Ph.D. dissertation, Department of Anthropology, Washington State University, Pullman.

Brown, James W., and James C. Chatters

2016 A Lithic Analysis of the Marymoor Site (45KI9): Development of a Seriation Using a Limited Stratified Sample. Paper presented at the 69th Annual Northwest Anthropological Conference, Tacoma, Washington.

Butler, B. Robert

1961 The Old Cordilleran Culture in the Pacific Northwest. Occasional Papers No. 5, Idaho State College Museum, Pocatello.

Chatters, James C.

1980 Original unpublished field notes from the Tualdad Altu (45KI59) data recovery excavations. Manuscript on file, Burke Museum, Seattle, Washington.

1994 Hells Canyon Archaeology, 1993: Dry Creek (10IH13) and Hells Canyon Creek (35WA78B). North American Paleoscience, Richland, Washington. Submitted to Hells Canyon National Recreation Area U.S. Forest Service. Copies available from Department of Anthropology, Central Washington University, Ellensburg. 
Chatters, James C., and Jason B. Cooper

2016 Eagle Gorge Terrace (45KI1083) an Upland Hunting Camp and Its Place in the Economic Lives of the Precontact Puget Salish. Journal of Northwest Anthropology 50:192-211.

Chatters, James C., Jason B. Cooper, Phillipe D. LeTourneau, and Laura C. Rooke

2011 Understanding Olcott: Data Recovery at 45SN28 and 45SN303, Snohomish County, Washington. AMEC Environment and Infrastructure. Submitted to Department of Public Works, Snohomish County, Washington. Copies available from AMEC Foster Wheeler, Bothell, Washington.

Chatters, James C., and Marc Fairbanks

2013 Archaeological Damage Assessment for the Bray Site (45PI1276). Applied Paleoscience. Submitted to Gary Bray, Edgewood, Washington, and the Washington Department of Archaeology and Historic Preservation (DAHP). Copies available from DAHP, Olympia, Washington.

Chatters, James C., David E. Rhode, and Karin A. Hoover 1990 Tualdad Altu (45KI59): A Prehistoric Riverine Village in Southern Puget Sound. Archaeology in Washington 2:23-48.

Cherkinsky, Alexander

2009 Can We Get a Good Radiocarbon Age from "Bad Bone"? Determining the Reliability of Radiocarbon Age from Bioapatite. Radiocarbon 51:647-655.

Cooper, Jason B.

2012 Howard A. Hanson Dam Archaeological District (DT 184) Data Recovery, Site Monitoring, and Cultural Resources Survey, King County, Washington. AMEC Environment \& Infrastructure. Submitted to U.S. Army Corps of Engineers, Seattle District. Copies available from the U.S. Army Corps of Engineers.

Daugherty, Richard D., J. Jeffrey Flenniken, and Jeanne M. Welch

1987 A Data Recovery Study of Layser Cave (45-LE223) in Lewis County, Washington. Western Heritage. Submitted to Gifford Pinchot National Forest, Vancouver, Washington. Copies available from Gifford Pinchot National Forest.

Diaz, Alejandra, Anna M. Prentiss, Rebecca McDonald, Olaf Nehlich, and Michael Richards

2017 Diet and Mobility on the Canadian Plateau: Isotopic Analysis of Domestic Dog and Other Fauna from the Bridge River Site. Paper presented at the 82nd Annual Meeting of the Society for American Archaeology, Vancouver, British Columbia.

Greengo, Robert E., and Robert Houston

1970 Excavations at the Marymoor Site. Reports in Archaeology No. 4, Department of Anthropology, University of Washington, Seattle.

Hackenberger, Steven, and R. W. Thompson

1995 Archaeological Investigations, Tryon Creek Site (35WA-288), 1991-1992, Hells Canyon Recreational Area, Wallowa County, Oregon. University of Wisconsin Centers. Submitted to the U.S. Department of Agriculture, U.S. Forest Service, Hells Canyon Recreation Area and Wallowa-Whitman National Forest. Copies available from Steven Hackenberger, Central Washington University, Ellensburg.

Holden, J. L., P. P. Phakeyu, and J. G. Clement

1995 Scanning Electronic Microscope Observations of Incinerated Human Femoral Bone: A Case Study. Forensic Science International 74:17-28.
Huls, C. M., H. Herkenkeuser, M. J. Nadeau, P. M. Grootes, and N. Andersen

2010 Experimental Study on the Origin of Cremated Bone Apatite Carbon. Radiocarbon 52:587-599.

Long, Austin, and Bruce Rippeteau

1974 Testing Contemporaneity and Averaging Radiocarbon Dates. American Antiquity 39:205-215.

Lanting, Jan N., Anita T. Aerts-Bijma, and Johannes van derPlicht

2001 Dating of Cremated Bone. Radiocarbon 43:249254.

Lohse, Ernest S., and C. Schou

2008 The Southern Columbia Plateau Projectile Point Sequence: An Informatics Approach. In Projectile Point Sequences in Northwestern North America, edited by Roy L. Carlson and Martin P. R. Magne, pp. 187-208. Archaeology Press, Simon Fraser University, Burnaby, British Colombia.

Lubinski, Patrick M., and Greg C. Burtchard

2005 Fryingpan Rockshelter (45PI43): A Subalpine Fauna in Mount Rainier National Park. Archaeology in Washington 11:25-34.

McCutcheon, Patrick T.

1992 Burned Archaeological Bone. In Deciphering a Shell Midden, edited by Julie K. Stein, pp. 347-370. Academic Press, New York.

McCutcheon, Patrick T., and Steve K. Dampf

2002 Central Washington University's 1998 Systematic Archaeological Survey in Mount Rainier National Park. Central Washington University. Submitted to National Park Service, Seattle. Copies available from Mount Rainier National Park.

McCutcheon, Patrick T., Anne B. Parfitt, James W. Brown, David R. Davis, Caitlin Limberg, and Sherri Middleton

2017 Investigating Intra-Site Variation for Holocene Epoch Human Land Use at the Sunrise Ridge Borrow Pit Site (45PI408). Central Washington Archaeological Survey, Central Washington University. Submitted to the National Park Service, Seattle, Washington. Copies available from the National Park Service.

Matson, R. G., and Gary Coupland

1995 The Prehistory of the Northwest Coast. Academic Press, New York.

Morgan, Vera E.

1999 The ST-101 Sequim Bypass Archaeological Project: Mid-to Late-Holocene Occupations on the Northern Olympic Peninsula, Clallam County, Washington. Eastern Washington University Reports in Archaeology and History 100-108. Archaeological and Historical Services, Cheney, Washington.

Nelson, Charles M.

1976 The Radiocarbon Age of the Biederbost Site (45SN100) and Its Interpretive Significance for the Prehistory of the Puget Sound Basin. Washington Archaeologist 20(1):1-17.

Ognibene, Ted J., Graham Bench, John S. Vogel, Graham F. Peaslee, and Steve Murov

2003 A High Through-Put Method for the Conversion of $\mathrm{CO}_{2}$ Obtained from Biochemical Samples to Graphite in Septa-Sealed Vials for Quantification of ${ }^{14} \mathrm{C}$ through Accelerator Mass Spectrometry. Analytical Chemistry 75:2192-2196.

Olsen, Jesper, Jan Heinemeier, Pia Bennike, Cille Krause, Karen M. Hornstrup, and Henrik Thrane

2008 Characterisation and Blind Testing of Radiocarbon Dating of Cremated Bone. Journal of Archaeological Science 35:791-800. 
Prentiss, Anna M.

2017 The Archaeology of the Fur Trade Occupation at Housepit 54. In The Last House at Bridge River: The Archaeology of an Aboriginal Household during the Fur Trade Period, edited by Anna M. Prentiss, pp. 42-66. University of Utah Press, Salt Lake City.

Prentiss, Anna M., Guy Cross, Thomas A. Foor, Matthew Hogan, Dirk Markle, and David S. Clarke

2008 Evolution of a Late Prehistoric Winter Village on the Interior Plateau of British Columbia: Geophysical Investigations, Radiocarbon Dating, and Spatial Analysis of the Bridge River Site. American Antiquity 73:5982.

Oetting, Albert C.

1994 The Archaeology of Buffalo Flat: Cultural Resources Investigations for the CONUSOTH-B Buffalo Flat Radar Transmitter Site, Christmas Lake Valley, Oregon. Heritage Research Associates. Submitted to U.S. Air Force. Copies available from Heritage Research Associates, Eugene, Oregon.

Randolph, Joseph E., and Max Dahlstrom

1977 Archaeological Test Excavations at Bernard Creek Rockshelter. University of Idaho Anthropological Research Manuscript Series, No. 42. Laboratory of Anthropology, University of Idaho, Moscow.

Reid, Ken C., and James C. Chatters

1997 Kirkwood Bar: Passport in Time Excavations at 10IH699 in the Hells Canyon National Recreation Area, Wallowa-Whitman National Forest. Rainshadow Research and Applied Paleoscience. Submitted to Wallowa-Whitman National Forest, Enterprise, Oregon. Report available from Applied Paleoscience, Bothell, Washington.

Rorabaugh, Adam N.

2015 Investigating Restricted Knowledge in Lithic Craft Traditions among the Pre-Contact Coast Salish. Ph.D. dissertation, Department of Anthropology, Washington State University, Pullman.

Shipman, Pat, Giraud F. Foster, and Margaret Schoeninger 1984 Burnt Bones and Teeth: Experimental Study of Color, Morphology, Structure, and Shrinkage. Journal of Archaeological Science 11:307-325.

Stafford, Thomas W., P. Edgar Hare, Lloyd Curie, A. J. Timothy Hull, and Douglas J. Donahue
1991 Accelerator Radiocarbon Dating at the Molecular Level. Journal of Archaeological Science 18:35-72.

Stiner, Mary C., Steven L. Kuhn, Stephen Weiner, and Ofer Bar-Yosef

1995 Differential Burning, Recrystallization, and Fragmentation of Archaeological Bone. Journal of Archaeological Science 22:223-327.

Surovell, Todd A., Joshua R. Boyd, C. Vance Haynes, and Gregory W. L. Hodgins

2016 On the Dating of the Folsom Complex and Its Correlation with the Younger Dryas, the End of Clovis, and Megafaunal Extinction. PaleoAmerica 2:81-89.

Taylor, R. E.

1987 Radiocarbon Dating: An Archaeological Perspective. Academic Press, New York.

Van Strydonck, Mark, Mathieu Boudin, and Guy De Mulder $2009{ }^{14}$ C Dating of Cremated Bones: The Issue of Sample Contamination. Radiocarbon 51:553-568.

Van Strydonck, Mark, Mathieu Boudin, Michiel Hoefkens, and Guy De Mulder

$2005{ }^{14} \mathrm{C}$ Dating of Cremated Bones, Why Does It Work? Lunula 13:3-10.

Zazzo, Antoine, Matthieu Lebon, Laurent Chiotti, Clothilde Comby, Emmanuelle Delqué-Kolic, Roland Nespoulet, and Ina Teiche

2013 Can We Use Calcined Bones for ${ }^{14} \mathrm{C}$ Dating the Paleolithic? Radiocarbon 55:1409-1421.

Zazzo, Antoine, and Jean-Francois Saliège

2011 Radiocarbon Dating of Biological Apatites: A Review. Paleogeography, Paleoclimatology, Paleoecology 310:52-61.

Zazzo, Antoine, Jean-Francois Saliège, Matthieu Lebon, Sebastien Lepetz, and Christophe Moreau

2012 Radiocarbon Dating of Calcined Bones: Insights from Combustion Experiments under Natural Conditions. Radiocarbon 54:844-866.

Zazzo, Antoine, Jean-Francois Saliège, Alain Person, and H. Boucher

2009 Radiocarbon Dating of Calcined Bones: Where Does the Carbon Come From? Radiocarbon 51:601611.

Submitted January 23, 2017; Revised March 17, 2017;

Accepted March 18, 2017 